Omni-Akuatika, 14 (2): 123 - 131, 2018
ISSN: 1858-3873 print / 2476-9347 online
Research Article

\title{
The Dynamics of Water Quality During Culture of Snakehead Fish (Channa striata) in The Aquarium
}

\author{
Dewi Puspaningsih ${ }^{1,2}$, Eddy Supriyono ${ }^{3}$, Kukuh Nirmala ${ }^{3}$ Iman Rusmana ${ }^{4}$, \\ Cecep Kusmana ${ }^{5}$, Ani Widiyati ${ }^{1}$ \\ ${ }^{1}$ Research Institute for Freshwater Aquaculture and Fisheries Extention, Bogor, Indonesia \\ ${ }^{2}$ Study Program of Aquaculture Science, Graduate School, Bogor Agricultural University, Bogor, Indonesia \\ ${ }^{3}$ Departement of Aquaculture, Faculty of Fisheries and Marine Science, Bogor Agricultural University, Bogor, \\ Indonesia \\ ${ }^{4}$ Departement of Biology, Faculty of Mathematics and Natural Sciences, Bogor Agricultural University, Bogor, \\ Indonesia \\ ${ }^{5}$ Departement of Silviculture, Faculty of Forestry, Bogor Agricultural University, Bogor, Indonesia
}

"Corresponding author: eddysupriyonoipb@gmail.com

\begin{abstract}
Intensive culture of snakehead fish used artificial feed with high protein content. The impact of the high use of artificial feed will cause waste that can cause poor water quality and cause fish mortality. The purpose of this research was to know the dynamics of water quality during culture of snakehead fish Channa striata in the aquarium. The test animals used were snakehead fish with a length of $6.90 \pm$ $0.49 \mathrm{~cm}$ and weight of $2.57 \pm 0.59 \mathrm{~g}$. Fish was maintenanced with a density of 2 fish $\mathrm{L}^{-1}, 4$ fish $\mathrm{L}^{-1}$ and 6 fish $\mathrm{L}^{-1}$. Fish was cultured for four days in an aquarium with size of $60 \times 40 \times 40 \mathrm{~cm}^{3}$ and water volume of $20 \mathrm{~L}$. Water quality were observed, i.e, temperature, $\mathrm{pH}$, dissolved oxygen, TAN, nitrite, nitrate, orthophosphate, hardness and alkalinity. The results showed that $\mathrm{pH}$, temperature, hardness, TAN, nitrite, nitrate and ortophosphate were not significantly different between treatments $(P>0.05)$, while dissolved oxygen and alkalinity were showed different significantly $(P<0.05)$. On the fourth day of culture with a density of 4 fish $\mathrm{L}^{-1}$ and 6 fish $\mathrm{L}^{-1}$ has led to water saturation in the culture media. Dynamic of water quality was started on the third day of culture, whereas nitrites could not be converted to nitrate maximally. High levels of nitrate in the snakehead culture indicated that that this culture could be combined with an integrated aquaculture with plants.
\end{abstract}

Keywords: water quality, snakehead fish, aquarium

\section{Introduction}

Snakehead fish (Channa striata) is a native species of Asia and Africa $(\mathrm{Ng}$ and Lim, 1990). This fish is one of the original fish that live in fresh waters in Indonesia, such as watersheds in Sumatra, Kalimantan and Java (Muthmainnah et al., 2012). In South Sumatra, the economic value continues to increase because snakehead fish can utilized in the form of fresh fish and also been used as the material of making crackers, pempek, tekwan and so on (Makmur, 2003). Utilization of these fish of various sizes, on the seeds size it was used as ornamental fish feed (Extrada et al., 2013) and on the size of fish consumption is very popular because it has a thick meat and a distinctive taste (Muthmaninnah et al., 2012).

While in the form of dried fish is processed into asapan fish or salted fish. Snakehead contains high enough albumin, according to Mustafa et al. (2012), the main fraction of fish protein extract of snakehead is albumin ( $64.61 \%$ of total protein). Snakehead albumin extract is relatively high $(2.17 \pm 0.14 \mathrm{~g} /$ $100 \mathrm{ml}$ ), enough to be used as ingredients to increase intake for growing children and patients undergoing wound healing treatments.

According to statistical data of the Ministry of Marine Affairs and Fisheries (2012), seen from the composition by fish species, the volume of capture fisheries production in public 
waters in 2012 is dominated by snakehead with production volume of 40.790 tons $(11.08 \%)$. The high yield of snakehead fishing in nature, it is feared will cause the occurrence of over fishing so that the stock in nature will decrease.

Efforts that can be done to overcome these problems is to conduct cultivation of snakehead fish so that its availability can be continuous and sustainable (Yulisman et al., 2011). Domestication and cultivation of snakehead ( $C$. striata) has been done in many Asian countries such as Indonesia, China, Malaysia, Thailand, Bangladesh, India (Yakob and Ali, 1992; Marimuthu et al., 2001; Amornsakun et al., 2011; Zhuo et al., 2012; Roy et al., 2016). Culture of snakehead fish at this time has not received much attention because of lack of information about culture technology (Astria et al., 2013). Considering the benefits of snakehead fish and its role in the world of health, the future of its culture will continue to grow, therefore it is necessary to do intensive culture so as to meet its needs continuously.

Research on stocking density of snakehead fish has many been done, such as Muthmainnah et al. (2012) mentions that the snakehead fish culture in karamba in swamp lebak produce the best survival rate with stocking density of 50 fish $\mathrm{m}^{-2}$, but the best weight increase with stocking density of 150 fish $\mathrm{m}^{-2}$. Almaniar et al. (2012) also mentioned that snakehead fish kept in density of 2, 3, 4, 5 and 6 fish $\mathrm{L}^{-1}$ showed the value of ammonia that tended to rise during the study with the increase of fish density. The higher the stocking density even though it gives lower final weights but can provide higher per $\mathrm{m}^{2}$ production (Muthmainnah, 2013). The survival of snakehead seeds in fiberglass tanks with recirculation systems using stocking densities of 20,30 and 40 fish $\mathrm{m}^{-2}$ was not significantly different, but the specific growth rate was significantly different between the density of 20 and 30 fish $\mathrm{m}^{-2}$ with a density of 40 fish $\mathrm{m}^{-2}$ (Amin et al., 2015).

Highly stocking density of fish at the beginning of culture will result in decreased water quality especially dissolved oxygen content and increased ammonia concentration. According to Lin et al. (2002), the accumulation of feed residue and fish excreta during culture often causes water quality deterioration in fishponds, resulting in toxic effects to fish. Aquaculture activity discharges contain considerable quantities of organic matter, nitrogen, and phosphorus and can further degrade the water quality in receiving water. About $36 \%$ of the feed is excreted as a form of organic waste (Brune et al., 2003) and around $75 \%$ of the feed $\mathrm{N}$ and $\mathrm{P}$ are unutilized and remain as waste in the water (Piedrahita, 2003). Decrease in water quality can cause stress to fish, even if water quality degradation has exceeded tolerance limits can cause fish disease and ultimately can cause death. The high number of fish mortality during the culture period may lead to a decrease in production (Crab et al., 2007). Zhang et al. (2011) mentioned that there were a strong association between fish production and water quality parameters. The spesific relationship were between the water quality parameters and culture efficacy (i.e., the final weight, survival rate, SGR and yield).

Research on environmental factors in snakehead fish culture in controlled containers is still very limited so that information about the dynamics of water quality during culture of snakehead fish is still very necessary. This study aims to evaluated the dynamics of water quality during culture of snakehead fish ( $C$. striata) in the aquarium.

\section{Materials and Methods}

This research was conducted in March, 2018. Culture of test fish (C. striata) was conducted in hatchery of Research Installation of Environmental Technology and Toxicology of Freshwater Aquaculture, Research Institute of Freshwater Aquaculture and Fishery Extension, Bogor, Indonesia. Measurement of water quality parameters were done in Environmental and Toxicology Laboratory, Research Installation of Environmental Technology and Toxicology of Freshwater Aquaculture, Bogor, Indonesia. Measurements of fish blood hematology parameters were conducted at the Fish Health Laboratory, Research Institute of Freshwater Aquaculture and Fishery Extension, Bogor, Indonesia (Blood hematology such as hemoglobin, red blood cell, white blood cell and hematocrit are closely related to individual responses to changes in environmental paramaters). Measurements of proximate analysis of fish feeds were conducted at the Laboratory of Animal Biology, Center for Biological Resource Research and Biotechnology, Bogor Agricultural University, Bogor, Indonesia.

This study was conducted in a hatchery using Completely Randomized Design. The treatment used in this research consisted of three fish density treatments, namely $A .2$ fish $\mathrm{L}^{-1}$, B. 4 fish $\mathrm{L}^{-1}$, C. 6 fish $\mathrm{L}^{-1}$ ). Each treatment with three replications. The test fish used in this study were snakehead fish seeds that were average length of $6.90 \pm 0.49 \mathrm{~cm}$ and the average weight was $2.57 \pm 0.59 \mathrm{~g}$. Fish kept in the aquarium equipped with aeration 
equipment. The culture container used is nine pieces of aquariums measuring $60 \times 40 \times 40$ $\mathrm{cm}$. Aquariums were filled with source water from well water that has been filtered using a filter bag. At the top of the aquarium completed with a net that function to prevent the fish jumping out of the aquarium. Aquarium in water content with volume $20 \mathrm{~L}$. Fish culture carried out for 4 days without water replacement process to see the dynamics of water quality during culture of snakehead fish. Fish in all treatments fed commercially with feed composition based on the results of the proximate analysis presented in Table 1, given three times per day as much as $2 \%$ of biomass weight per day.

Table 1. The proximate analysis of commercial feed used in the present study

\begin{tabular}{l|l}
\hline Chemical composition & $\begin{array}{l}\text { Content (\% dry } \\
\text { weight) }\end{array}$ \\
\hline Protein & 35.24 \\
Fat & 6.98 \\
Crude fiber & 1.47 \\
Ash & 8.97 \\
Moisture & 9.40 \\
\hline
\end{tabular}

Observations and measurements of temperature, $\mathrm{pH}$, dissolved oxygen, total ammonia nitrogen, nitrite, nitrate, orthophosphate, alkalinity and hardness were done daily, while analysis of hematological parameters of fish blood was done at the beginning and at the end of the study. The method used for the measurement of such parameters is temperature using $\mathrm{SNI} 06$ 6989.23-2005, pH using SNI 06-6989.11-2004, dissolved oxygen using SNI 06-6989.14-2004, total ammonia nitrogen using SNI 06-6989.302005, nitrite using SNI 06-6989.29-2004, nitrate using APHA, orthophosphate using SNI 066989.31-2005, alkalinity using Standard Methods 403 and total hardness using SNI 066989.12-2004.

Sampling and hematological analysis of fish blood (red blood cells, white blood cells, hemoglobin and hematocrit) and fish blood glucose were performed at the beginning and end of the observation.

The analytical methods used for the measurement of some parameters were red blood cells and white blood cells using Blaxhall and Daisley (1973), hemoglobin using Wedemeyer and Yasutake (1977), hematocrit using Anderson and Siwicki (1995), and blood glucose using blood kit.

All data (physical and chemical water parameters and hematology of snakehead fish) were analyzed using descriptive.

\section{Results and Discussion}

Data obtained from measurements of physical-chemical parameters are presented in Table 2 (dissolved oxygen, $\mathrm{pH}$, temperature, alkalinity and total hardness).

Table 2. The value of physical-chemical parameters of the water in each treatment during the study

\begin{tabular}{lcccc}
\hline \multirow{2}{*}{ Parameters } & \multicolumn{3}{c}{ Treatments } & Tolerance \\
\cline { 2 - 4 } & $\mathrm{A}$ & $\mathrm{B}$ & $\mathrm{C}$ & range \\
\hline $\mathrm{DO}\left(\mathrm{mg} \mathrm{L}^{-1}\right)$ & $3.14 \pm 0.39^{\mathrm{ab}}$ & $3.85 \pm 0.49^{\mathrm{a}}$ & $2.53 \pm 0.64^{\mathrm{b}}$ & $0,2-8,6^{1)}$ \\
$\mathrm{pH}$ & $7.14 \pm 0.25^{\mathrm{a}}$ & $6.97 \pm 0.42^{\mathrm{a}}$ & $7.16 \pm 0.41^{\mathrm{a}}$ & $4-9^{1)}$ \\
Temperature & $26.25 \pm 0.21^{\mathrm{a}}$ & $26.20 \pm 0.29^{\mathrm{a}}$ & $26.33 \pm 0.15^{\mathrm{a}}$ & $26,8-32,5^{1)}$ \\
$\left({ }^{\circ} \mathrm{C}\right)$ & & & \\
$\begin{array}{l}\text { Alkalinity }\left(\mathrm{mg} \mathrm{L}^{-}\right. \\
\left.{ }_{1}^{1}\right)\end{array}$ & $68.65 \pm 5.84^{\mathrm{a}}$ & $64.07 \pm 25.65^{\mathrm{a}}$ & $39.66 \pm 2.50^{\mathrm{b}}$ & $30-500^{2)}$ \\
$\begin{array}{l}\text { Total Hardness } \\
\left(\mathrm{mg} \mathrm{L}^{-1}\right)\end{array}$ & $206 \pm 62.87^{\mathrm{a}}$ & $175.75 \pm 67.96^{\mathrm{a}}$ & $149.75 \pm 65.17^{\mathrm{a}}$ & $120-500^{2)}$ \\
& & & &
\end{tabular}

${ }^{11} \mathrm{KKP}(2014),{ }^{2)}$ Effendi (2003)

Mean values in the same row with different superscript letters are significantly different $(P<0.05)$

Dissolved oxygen value measured at each treatment during the study ranged from $1.94-4.43 \mathrm{mg} \mathrm{L}^{-1}$, still within the tolerable tolerance range of snakehead fish according to Ministry of Marine Affairs and Fisheries (2014) $(0.2$ - 8.6). This range is below the value obtained by Amin et al. (2015) which states that dissolved oxygen on culture medium of snakehead fish farming with difference stocking density $\left(20,30\right.$ and 40 fish $\left./ \mathrm{m}^{2}\right)$ ranges from 5.21 to $5.32 \mathrm{mg} \mathrm{L}^{-1}$. The average $\mathrm{DO}$ in treatment $A$ of $3.14 \mathrm{mg} \mathrm{L}^{-1}$ was not significantly different $(P>0.05)$ with treatment $B$ that is equal to $3.85 \mathrm{mg} \mathrm{L}^{-1}$ and with treatment $\mathrm{C}$ of $2.53 \mathrm{mg}$ 
$\mathrm{L}^{-1}$, whereas $\mathrm{DO}$ in treatment $\mathrm{B}$ was significantly different $(P<0.05)$ with treatment $\quad C$. This indicated that $\mathrm{DO}$ at stocking densities of 2 fish $\mathrm{L}^{-1}$ and 4 fish $\mathrm{L}^{-1}$ were still quite high with values that were not significantly different $(P>0.05)$, whereas at density of 6 fish $\mathrm{L}^{-1} \mathrm{DO}$ values are measured lower. Effendi (2003) mentioned that fish and other aquatic organisms require sufficient amounts of dissolved oxygen and oxygen demand is greatly influenced by temperature and varies among organisms. On the other hand Boyd (1982) also mentions that the rate of oxygen consumption by fish varies depending on species, size, activity, temperature, nutritional state, and others.

Snakehead fish are classified as airbreathing fish that can survive in poor environments with low dissolved oxygen content and high ammonia content (Marimuthu and Haniffa, 2007). In this study where snakehead fish were kept in controlled environment (aquarium) was proved by feeding as much as $2 \%$ biomass weight per day giving water quality dynamics on medium culture of fish significantly until the fourth day.

The $\mathrm{pH}$ values obtained during the study ranged from 6.55 to 7.44 , still within the tolerance range tolerated by snakehead fish according to Ministry of Marine Affairs and Fisheries (2014) (4 - 9). The $\mathrm{pH}$ value in this experiment were not significantly different $(P>$ 0.05 ). This $\mathrm{pH}$ value is higher when compared to the results of research Amin et al. (2015) who get $\mathrm{pH}$ value ranges from 5.21 to 5.32 . According to Boyd (1982) most natural waters have a pH between $6.5-9$, but waters are more acidic than $\mathrm{pH} 6.5$ or more alkaline than $\mathrm{pH} 9$ 9.5 for long periods, reproduction and growth will decrease.

The temperatures in this study are low at 26.0-26. $6^{\circ} \mathrm{C}$, the tolerance range according to Ministry of Marine Affairs and Fisheries (2014) that can be tolerated by snakehead fish ranging from $26.8-32.5^{\circ} \mathrm{C}$. The temperature value in this experiment were not significantly different $(P>0.05)$. The snakehead fish in this study can tolerate lower temperatures than the Ministry of Marine Affairs and Fisheries (2014) is thought to be caused by snakehead fish having been adapted for a long time in a hatchery in Bogor. According to Qin and Fast (1998), snakehead fish gained significantly more weight at high temperature than at low temperature.

The value of alkalinity in this study ranged from 30.51 - 91.53, still within the appropriate tolerance range for fish according to Effendi (2003) ranging from 30 to 500 . Alkalinity in treatment $A$ was not significantly different from treatment $B(P>0.05)$, but alkalinity $A$ and $B$ were significantly different from treatment $C \quad(P<0.05)$. Boyd (1982) mentions natural waters containing $40 \mathrm{mg} \mathrm{L}^{-1}$ or more of total alkalinity are considered more productive than waters with lower alkalinity. The greater productivity of waters with higher alkalinity is not directly induced by alkalinity, but rather caused by phosphorus and other nutrients that increase in common with total alkalinity.

The total hardness value in this study ranged from 90 - 255, while the total tolerance range according to Effendi (2003) ranged from 120 - 500. The total hardness value in this experiment were not significantly different $(P>$ 0.05). Boyd (1982) mentioned that total hardness is usually associated with total alkalinity, since the anions of alkalinity and cation of hardness usually originate from carbonate mineral solutions. If total hardness is greater than total alkalinity, some calcium and magnesium are associated with anions rather than bicarbonates and carbonates. Conversely, if the total alkalinity of water exceeds its total hardness, some bicarbonate and carbonate are more associated with sodium and calcium than calcium and magnesium.

Data of TAN, nitrite, nitrate and orthophosphat are presented in Figure 1, 2, 3 and 4 respectively. 


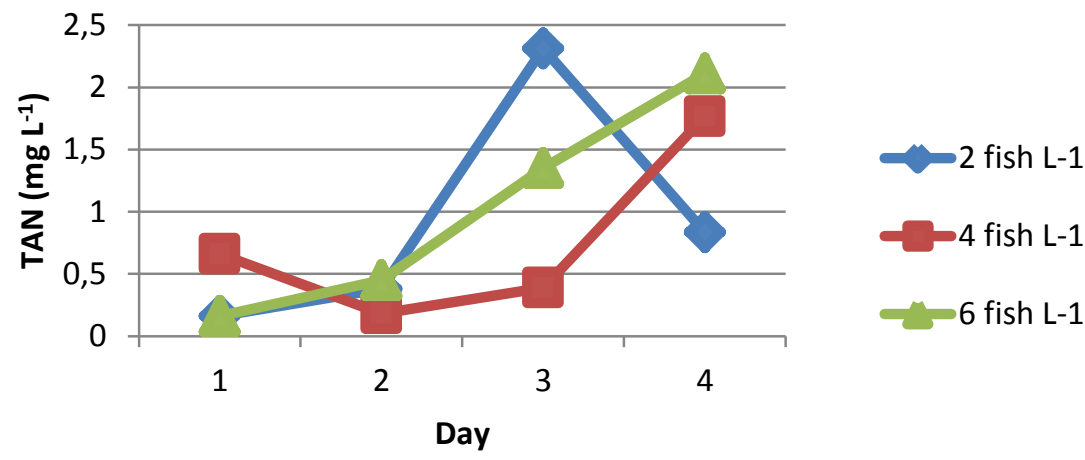

Figure 1. TAN value during the study

From Figure 1 it can be seen that the water quality dynamics during the four days culture of snakehead fish in the aquarium show significant values on days 3 and 4 in fish density of 4 and 6 fish $\mathrm{L}^{-1}$ but there were no significant different between treatments $(P>0.05)$. At the density of 2 fish $L^{-1}$, the TAN value tended to rise on day 3 , but decreased on day 4 . At density of 6 fish $\mathrm{L}^{-1}$, the TAN value on the fourth day reached $2.11 \mathrm{mg} \mathrm{L}^{-1}$. Qin et al. (1997) mentioned that snakehead fish kept on culture medium with $\mathrm{pH} 8.0$ will get TAN value of $10.73 \mathrm{mg} \mathrm{L}^{-1}$ while tolerance of snakehead fish at $\mathrm{pH} 8.0$ to $\mathrm{LC}_{50}$ ammonia at $24,48,72$ and 96 hours is >205.7, >203.5, 152.6 and $107.3 \mathrm{mg} \mathrm{TAN} \mathrm{L}^{-1}$. The measured TAN value is the sum of $\mathrm{NH}_{3}$ and $\mathrm{NH}_{4}{ }^{+}$, free ammonia $\left(\mathrm{NH}_{3}\right)$ can not be ionized, while ammonium $\left(\mathrm{NH}_{4}{ }^{+}\right)$can be ionized (Effendi, 2003). $\mathrm{NH}_{3}$ can be toxic for aquatic organisms, $\mathrm{NH}_{3}$ toxicity to aquatic organisms will increase if there is a decrease in dissolved oxygen, $\mathrm{pH}$ and temperature (Effendi, 2003).

According to Boyd (1982) the effect of $\mathrm{pH}$ on the concentration of non-ionized ammonia is greater than the effect of temperature. Boyd (1982) also mentions that if the ammonia levels rise in water, the excretion of ammonia by the fish decreases and the ammonia levels in the blood and tissues increase. This can lead to an increase in the fish's blood $\mathrm{pH}$ and adversely affects the reaction of the enzyme catalyst and the stability of the membrane. High ionized ammonia concentrations in water affect the permeability of fish by water and reduce ion concentration in the body. Ammonia also increases oxygen consumption by tissues, damages gills and reduces the ability of blood to transport oxygen.

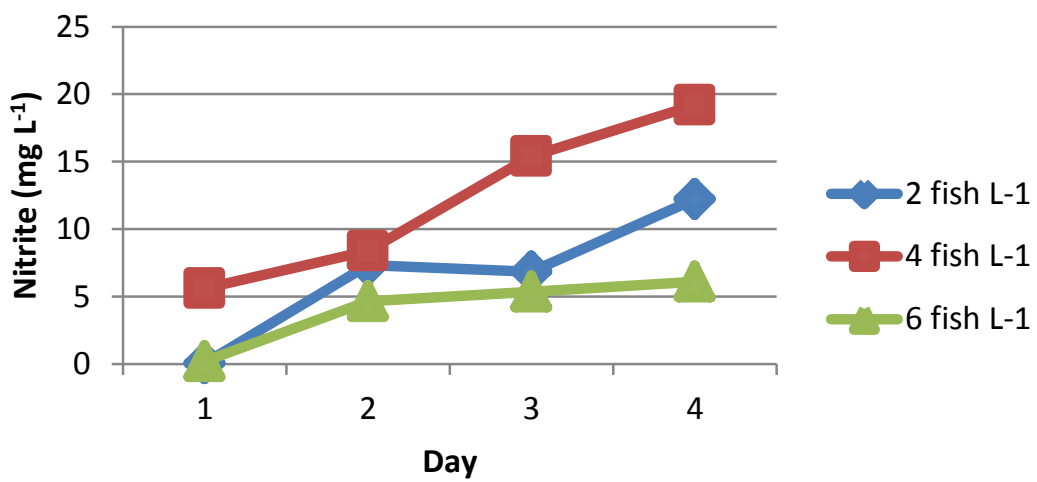

Figure 2. Nitrite value during the study 
The nitrite values in this study showed a trend that always increased until the fourth day, a significant increase began on the second day, where at density 2,4 and $6 \mathrm{~L}^{-1}$ obtained values of $7.35 \mathrm{mg} \mathrm{L}^{-1} ; 8.4 \mathrm{mg} \mathrm{L}^{-1} ; 4.65 \mathrm{mg} \mathrm{L}^{-1}$ respectively. The nitrite values showed no significantly different between treatments $(P>0.05)$. On the fourth day the value of nitrite ranged from $6.1-19.2 \mathrm{mg} \mathrm{L}^{-1}$, this value is very high. According to Boyd (1982), when nitrite is absorbed by fish, nitrites react with hemoglobin become methemoglobin.
Methemoglobin is known to be ineffective as an oxygen carrier, so the continuous absorption of nitrite can lead to hypoxia and cyanosis. Blood that contains a lot of methemoglobin colored brown, so that nitrite poisoning in fish is often referred to as brown blood disease. Nitrite comes from the reduction of nitrate by bacteria in mud or anaerobic water. However, a common opinion is that the imbalance in nitrification reactions raises the accumulation of nitrite.

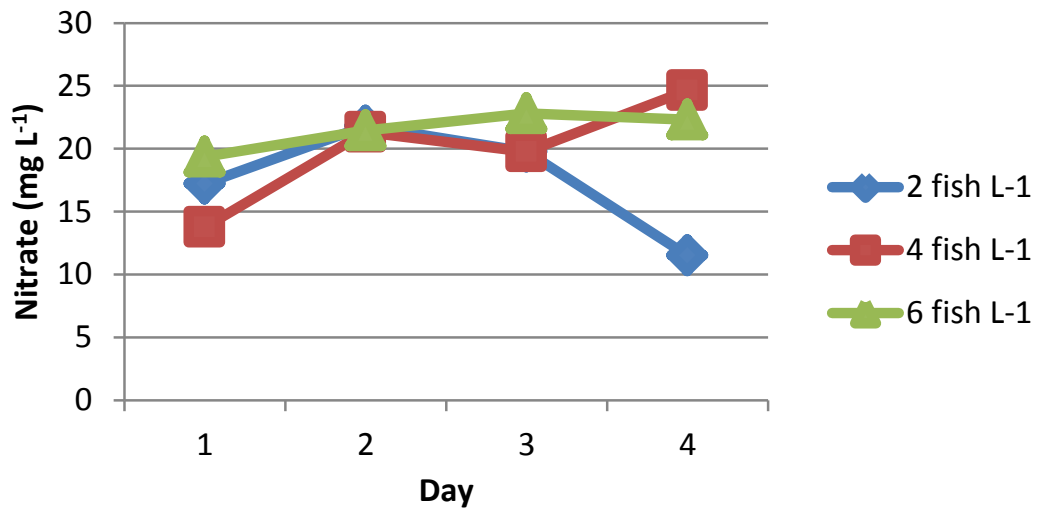

Figure 3. Nitrate value during the study

The nitrate value in this study is quite high, ranging from $11,505-24.64 \mathrm{mg} \mathrm{L}^{-1}$, but there were no significantly different between treatments $(\mathrm{P}>0.05)$. Nitrate $\left(\mathrm{NO}_{3}\right)$ is an $\mathrm{N}$ form which tends to be harmless to fish compared to nitrite $\left(\mathrm{NO}_{2}\right)$ and ammonia $\left(\mathrm{NH}_{3}\right)$. Inorganic form of nitrogen such as $\mathrm{NO}_{3}$ is actually an ionic form that can be directly utilized by plants for life. According to Effendi (2003) nitrates are highly water-soluble and stable, these compounds are produced from the perfect oxidation process of nitrogen compounds in the waters.
Nitrification which is the process of oxidation of ammonia to nitrites and nitrates is an important process in the nitrogen cycle and takes place under aerobic conditions. The presence of excess nitrate in the culture of snakehead indicates that the culture of snakehead fish with high density can also be combined with an integrated aquaculture with plants, so that nitrate can be utilized directly by the plant and become its own added value in the snakehead fish culture.

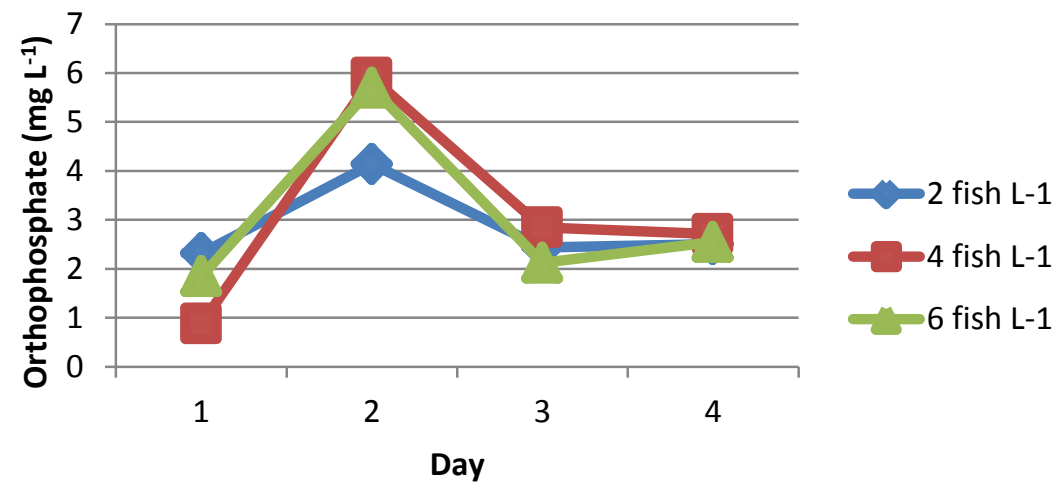

Figure 4. Orthophosphate value during the study 
The value of orthophosphate in this study ranged from 0.88 to $5.9 \mathrm{mg} \mathrm{L}^{-1}$ and showed no significantly different between treatments $(P>0.05)$. The value of orthophosphate increased significantly on the second day, ranging from 4.14 to $5.9 \mathrm{mg} \mathrm{L}^{-1}$, but then on days 3 and 4 decreased to $2.51-2.71 \mathrm{mg} \mathrm{L}^{-1}$. According to Effendi (2003), orthophosphate is a form of phosphorus that can be utilized directly by aquatic plants, whereas polyphosphates must undergo hydrolysis to form orthophosphate before it can be used as a source of phosphorus. Changes in polyphosphates into form of orthophosphates depending on temperature.

At the temperature approaching the boiling point, the polyphosphate change into orthophosphate is rapid. This speed increases with decreasing $\mathrm{pH}$ value. Changes of polyphosphate to orthophosphate in wastewater containing bacteria progresses faster than changes in clean water. Orthophosphates are also forms of ions that can be directly absorbed by plants so according to Effendi (2003) the presence of excessive phosphorus accompanied by the presence of nitrogen can stimulate the explosion of algae growth in the waters.
Data obtained from measurements of blood hematology of fish and blood glucose from snakehead fish culture with density treatment are presented in table 3.

From table 3 it can be seen that hemoglobin, hematocrit and blood glucose levels of snakehead fish increased after four days of culture, while the number of red blood cells and white blood cells decreased. The blood glucose value of snakehead fish before treatment ranged between 49.8 - $50 \mathrm{mg} / 100$ $\mathrm{mL}$ and after treatment ranged between $60-70$ $\mathrm{mg} / 100 \mathrm{~mL}$. This value tends to be greater than that of Purnamawati et al. (2017) which states that the snakehead fish kept in the culture media condition using sulfuric acid water has blood glucose level of $29.99 \mathrm{mg} / 100 \mathrm{~mL}$ and in the condition of culture media using rain water of $26.45 \mathrm{mg} / 100 \mathrm{~mL}$. The high energy needed to survive will stimulate the deployment of glucose into the blood. This suggests that the stocking density treatment in this study makes the snakehead fish mobilize large enough energies so that it make blood glucose levels rise.

Table 3. Fish blood haematology before and after treatment

\begin{tabular}{lcc}
\hline \multicolumn{1}{c}{ Haematology } & Before treatment & After treatment \\
\hline Red blood cell $\left(\mathrm{sel} / \mathrm{mm}^{3}\right)$ & $2.17 \times 10^{6}-2.47 \times 10^{6}$ & $20 \times 10^{4}-21 \times 10^{4}$ \\
White blood cell $\left(\mathrm{sel} / \mathrm{mm}^{3}\right)$ & $7.55 \times 10^{3}-11.1 \times 10^{3}$ & $2.95 \times 10^{3}-5.7 \times 10^{3}$ \\
Haemoglobin $(\%)$ & $8.1-11$ & $16.5-22.5$ \\
Hematokrit $(\%)$ & $33-55$ & $76-78$ \\
Blood glucose & $49.8-50$ & $60-70$ \\
$(\mathrm{mg} / 100 \mathrm{~mL})$ & & \\
\hline
\end{tabular}

Some parameters that can show pathological changes in blood are hematocrit, hemoglobin, red blood cell count and white blood cell count. In this study the number of red blood cells of snakehead fish before treatment ranged between $2.17 \times 10^{6}-2.47 \times 10^{6}$ cells / $\mathrm{mm}^{3}$ while after treatment ranged from $20 \times 10^{4}$ $-21 \times 10^{4}$ cells $/ \mathrm{mm}^{3}$. The number of white blood cell before treatment in this researh were ranged from $7.55 \times 10^{3}-11.1 \times 10^{3}$ while after treatment ranged from $2.95 \times 10^{3}-5.7 \times 10^{3}$.

In normal fish, the number of red blood cells ranges from $1.05-3.00 \times 10^{6}$ cells $/ \mathrm{mm}^{3}$ of blood (Roberts, 1978). The number of red blood cells of snakehead fish that tends to be higher than normal fish blood cell counts is thought to be related to the activity of snakehead fish that always takes oxygen directly from the air. Well et al. (2005) states that Tarpon fish that can take oxygen directly from the air has a higher red blood cell count when compared to salmon catfish. Graham (1997) also mentioned that it has been observed that blood parameters such as haematocrit, haemoglobin concentration and red blood cells count are related to environmental factors such as water temperature and salinity.

Haemoglobin number before treatment in this research ranged from $8.1-11$, while after treatment ranged from $16.5-22.5$. Weber and Wells (1989) mentioned that the relationship between haemoglobin and oxygen differs between loading and unloading sites and shows adaptations not only to environmental conditions but also to metabolic requirements, both of which govern oxygen availability and transport to tissues.

Haematocrit number before treatment ranged from $33-55$, while after treatment tend 
to increased ranged from $76-78$. According to Jawad et al. (2004), increased levels of hematocrit influenced by two factors, the first one is changes in environmental parameters, especially water temperature and physiological state of the fish associated with the energy needed. Jawad et al. (2004) also mentioned that several authors have shown how environmental factors such as water temperature have a direct effect on different blood parameters such as haematocrit through their effect on the haemoglobin oxygen-binding properties and thus on oxygen transport.

\section{Conclusions}

The dynamics of water quality during culture of snakehead fish (C. striata) in the aquarium showed a significant increase in nitrite level from the $3^{\text {rd }}$ day, whereas nitrite can not be converted to nitrate maximally, so that it tend to increased. The surplus of nitrate in the culture of snakehead indicated that the culture with high density could also combined with an integrated aquaculture with plants.

\section{Acknowledgements}

This research was funded by Ministry of Marine Affairs and Fisheries which gave The Scholarship and Research Institute for Freshwater Aquaculture for the supporting location and tools. The first author gratefully acknowledge to Prof. D. Djokosetiyanto (in memory) for all supporting.

\section{References}

Almaniar, S., Taqwa, F.H., Jubaedah, D. 2012. Pertumbuhan dan kelangsungan hidup benih ikan gabus (Channa striata) selama pemeliharaan dengan padat penebaran berbeda. Majalah IImiah Sriwijaya. 22(15), 46-55.

Amin, S.M.N., Muntaziana, M.P.A., Kamarudin, M.S., Rahim, A.A., Rahman, M.A. 2015. Effect of different stocking densities on growth and production performances of Chevron snakehead Channa striata in Fiberglass tanks. North American Journal of Aquaculture. 77, 289-294.

Amlacher, E. 1970. Textbook of fish disease.

DA Conroy, RL Herman (Penerjemah).

TFH Publ. Neptune. New York, 1, 1-14.

Amornsakun, T., Sriwatana, W., Promkaew, P. 2011. Feeding behaviour of snake head fish, Channa striatus larvae. Songklanakarin Journal of Science and
Technology. 33(6), 665-670.

Anderson, DP., AK Siwicki. 1995. Basic hematology and serology for fish health programs. Paper presented in second symposium on diseases in Asian Aquaculture "Aquatic Animal Health and the Environment". Phuket, Thailand. 25 - 29thOctober 1993. 17p.

Astria, J., Marsi, Fitrani, M. 2013. Survival rate and growth of snakehead fish (Channa striata) on various $\mathrm{pH}$ modification of swamp water mixed with soil substrat. Jurnal Akuakultur Rawa Indonesia, 1(1), 66-75.

Blaxhall, PC., K.W. Daisley. 1973. Routine haematological methods for use with fish blood. J. Fish Biol. 5, 577-581.

Boyd, C.E. 1982. Water Quality in Ponds for Aquaculture. Auburn university of agriculture station. Alabama (USA):

Brune, D.E., Schwartz, G., Eversole, A.G., Collier, J.A., Schwedler, T.E. 2003. Intensification of pond aquaculture and high rate photosynthetic systems. Aquaculture Engineering. 28, 65-86.

Crab, R., Avnimelech, Y., Defoirdt, T, Bossier, P., Verstraete, W. 2007. Nitrogen removal technique in aquaculture for a sustainable production. Aquaculture. 270, 1-14.

Effendi, H. 2003. Telaah kualitas air bagi pengelolaan sumber daya perairan dan lingkungan. 256p.

Extrada, E., Taqwa, F.H., Yulisman. 2013. Survival and growth rate of snakehead juvenile (Channa striata) at different levels of water elevation on rearing media. Jurnal Akuakultur Rawa Indonesia, 1(1), 103-114.

Graham, J.B. 1997. Air-breathing fishes: Evolution, diversity, and adaptation. Academic Press, San Diego.

Jawad, L.A., Al Mukhtar, M.A., Ahmed, H.K. 2004. The relationship between hematocrit and some biological parameters of the Indian Shad Temalosa ilisha. Animal Biodiversity and Concervation, 27, 47-52.

[KKP] Kementerian Kelautan dan Perikanan. 2012. Statistik Perikanan Tangkap Indonesia, Vol.13 No.1, 13p.

[KKP] Kementerian Kelautan dan Perikanan. 2014. Naskah akademik ikan gabus 
haruan (Channa striata Bloch 1793) hasil domestikasi. 74p.

Lin, Y.F., Jing, S.R., Lee, D.Y., Wang, T.W. 2002. Nutrient removal from aquaculture wastewater using a constructed wetlands system. Aquaculture 209, 169-184.

Makmur, S. 2003. Biologi reproduksi, makanan dan pertumbuhan ikan gabus (Channa striata Bloch) di daerah banjiran Sungai Musi, Sumatera Selatan. Tesis. Pasca Sarjana, IPB. 72p.

Marimuthu, K., Haniffa, M.A., Muruganandam, M., Raj, A.J.A. 2001. Low cost murrel seed production technique for fish farmers. Naga, The ICLARM quarterly. 24(1\&2), 21-22.

Marimuthu, K., Haniffa, M.A. 2007. Embyonic and larval development of the striped snakehead Channa striatus. Taiwania, 52(1), 84-92.

Muthmainnah, D., Nurdawati, S., Aprianti, S. 2012. Budidaya ikan gabus (Channa striata) dalam wadah karamba di rawa lebak. Prosiding InSINas, 319-323.

Muthmainnah, D. 2013. Growout of striped snakehead (Channa striata) in swamp water system using fences and cages. $4^{\text {th }}$ International Conference on Biology, Environment and Chemistry. 58, 52-55.

Mustafa, A., Widodo, M.A., Kristianto, Y. 2012. Albumin and zinc content of snakehead fish (Channa striata) extract and its role in health. International Journal of Science and Technology (IJSTE), Vol.1 No.2, June 2012, 1-8.

Ng, P.K., Lim, K.K.P. 1990. Snakeheads (Pisces: Channidae): Natural history, biology and economic importance. In: Ming CL dan Ng PKL (Editors), Essays in Zoology. Papers commemorating the $40^{\text {th }}$ Anniversary of the Department of Zoology, National University of Singapore, 127-152.

Piedrahita, R.H. 2003. Reducing the potential environmental impacts of tank aquaculture effluents through intensification and recirculation. Aquaculture 226, 35-44.

Purnamawati, Djokosetiyanto, D., Nirmala, K., Harris, E., Affandi, R. 2017. Survival and growth of stiped snakehead fish (Channa striata Bloch.) juvenile reared in acid sulfate water and rainwater medium. AACL Bioflux, 2017, Nolume 10, Issue 2, 265-273.
Qin, J., Fast, A.W., Kai, A.T. 1997. Tolerance of snakehead Channa striatus to Ammonia at different $\mathrm{pH}$. Journal of the world aquaculture society. Vol.28,no.1, March 1997, 87-90.

Qin, J.G., Fast, A.W. 1998. Effects of temperature, size and density on culture performance of snakehead, Channa striatus (Bloch), fed formulated feed. Aquaculture Research 29, 299-303.

Rastogi, S.C. 1977. Essential of Animal Physiology. Wiley Eastern Limited. New Delhi, Belangmore, Clcutta. 204-233p.

Roberts, R.J. 1978. Fish pathology. Bailliere Tindal. London.

Roy, N.C., Chowdhury, S.K., Das, S.K. 2016. Observation of hapa breeding technique of striped snakehead, Channa striatus (Bloch, 1793) under captive condition. International Journal of Fisheries and Aquatic Studies. 4(5), 413-417.

Weber, R.E., Wells, R.M.G. 1989. Hemoglobin structure and functioni. In: Comparative pulmonary physiology. Marcel Dekker, New York, 279-310.

Wedemeyer, GA., WT Yasutake. 1977. Clinical methods for the assessment of the effect on environmental stress on fish health. Technical Papers of the U.S. Fish and Wildlife Service. US depert. Of the Interior. J. Fish and Wildlife Service 89, 1 - 17

Well, R.M.G., Baldwin, J., Seymour, R.S., Christian, K., Britain, T. 2005. Blood cell function and haematology in two tropical freshwater fishes from Australia. Comparative Biochemistry and Physiology. (A), 141, 87-93.

Yaakob, W.A.A., Ali, A.B. 1992. Simple method for backyard production of snakehead (Channa striata Bloch) fry. Naga. 15, 2223.

Yulisman, Jubaedah, D., Fitrani, M. 2011. Pertumbuhan dan kelangsungan hidup benih ikan gabus (Channa striata) pada berbagai tingkat pemberian pakan. Jurnal Pena Akuatika. 3(1), 43-48.

Zhuo, X., Liang, R., Chen, Y., Huang, G., Yu, D., Zou, J. 2012. Genetic characterization of northern snakehead (Channa argus) populations in China using microsatellite markers. Biochemical Systematics and Ecology. 43, 25-31. 